\title{
Job Stress and Inscecurity Among the Employees in Food Delivery Services
}

\author{
ANKIT KATRODIA \\ Lecturer- North West University \\ School of Management Sciences \\ Private Bag X2046, Mmabatho 2735, SOUTH AFRICA
}

\begin{abstract}
The growth of technology and change of lifestyle has led to the enormous growth of the food delivery services in the recent times. Food ordering through online is the way of ordering customers preferred food by using website of the restaurant or food delivery apps[14] One out of every four customer makes use of a food ordering app in their mobile which was revealed in recent study. Online food delivery created a new wave in the Indian food industry. Ordering food through online has created a strong reflection in people's mind and multiple factors are attracted which includes purchase power of the people, awareness about upcoming trends, various payment options, widespread of internet access and offers and discount provided by the companies. The Delivery employees at startups such as Swiggy, Zomato and uber are earning good income by doing delivery of goods. In spite of salary the employees working in this sector are facing lot of problems and it leads to job stress. The job stress and insecurity of employees working in food delivery service has been considered for the study. Convenience sampling method has been used to collect data from 150 employees. The result reveals that working hours is the important factor which leads to stress.
\end{abstract}

Key Words: Food Delivery, Job Stress, Job Insecurity, Job Satisfaction

Received: March 12, 2020. Revised: October 19, 2020. Accepted: October 23, 2020.

Published: October 26, 2020.

\section{Introduction}

The change of technological advancement and busy lifestyle has paved broad way to the Online Food Delivery services to develop and expand their business. These food delivery companies' reaches their customers through websites and mobile application where in the customers can specify their order [14]. Food ordering through online is the way of ordering customers preferred food by using website of the restaurant or food delivery apps. Customers' preference is the main criteria for choosing their choice of food. While ordering food the customers always choose their preferred restaurant, various menu items, selecting the item of their choice and finally choose the delivery and pick up options. Usually the customers payment option includes, using debit or credit card, payment apps or cash on delivery. The update about food quality, preparation and

finishing time, pick-up and delivery details will be displayed through the app [14]. The progress of the delivery and expected delivery time can be tracked by the customers by using a website or mobile app. Customer location, nearby restaurants and hotel details are provide through Google maps, which is the backbone and success for these service providers. Whenever a customer makes an order the message goes over to the mainframe. It then gets conveyed to the person who is nearest to the pick-up and delivery points. 


\section{Review of Literature}

Wilfred Isioma Ukpere and Nnenne E Ukandu (2014) have conducted a study on, "Factors impacting job satisfaction of employees in the fast food industry in Cape Town". The study has focused on Job satisfaction fast food outlets in Cape Town. The employees working in fast food outlets are unique and they have to satisfy their own individual needs. The employees who have at least six months experience have been considered for the study. The data has been collected from the employees working both at administrative and operational level [13] The questionnaires consist of 200 closed-ended questions, and it has been distributed 123 employees working in the fast food industry and the response rate is $62.5 \%$. The finding shows that the employees are not satisfactory and their personal growth is not up to the mark. Hence, the researcher has suggested for effective participation in decision making and proper skill training to be given to the employees.

Goh See-Kwong, Soo-Ryue and Wong Shiun-Yi (2017) have conducted a research titled "A study on outsourcing to online food delivery services". The study tends to find the perspective of respondents offering delivery services through third party online platform. The research study on business owner's perspective in relation to outsourcing food delivery service is found to be limited. Twelve respondents who are currently offering outsourcing service has been considered for the study. The questionnaire which include outsourcing decisions and motivating factors [5]. The findings shows that most significant impact while outsourcing third party online food delivery service is increase in revenue and exposure Online service plays major role in improving the customer satisfaction. So the companies should concentrate more on satisfying the needs of the customer, experience in payment modes, reviews and ratings
Meenatchi Somasundari (2018) conducted a study on, "Mechanism of job satisfaction and job performance among the selected online food delivery services". The research adopts analytical research design and has the primary objectives as to know the effect of stress on job performance of online food delivery executives. 100 Samples have been considered by using convenient random sampling method for collecting the data. To find out the important dimensions of stress and its impact on demographic variables chi-square test, independent $t$ sample test has been used for the study. The study found that job satisfaction is the major factor which affects the performance of the employees [7]. It was found that the job stress directly affects the functioning of the workers in the online food delivery industry.

\subsection{Employees in Food Delivery Service}

Delivery employees at startups such as Swiggy, Zomato and Uber are earning good income by doing food delivery and earn between 15,000 and 40,000 per month, depending on factors such as the number of deliveries finished and the distance they cover. Promising earnings is the main advantage for the employees who are selecting this job. Composite structure in wage payment and incentives are the added benefit for the employees. Incentive is the main attractive package for these employees and which includes, weekday, weekend and monthly incentives. The employees also get an additional incentive during rainy days and late night shifts. Deliveries will be peak during evenings to night. Food delivery employees will be provided the address of the restaurants and the delivery points. They need to pick them up from the restaurants or hotels correctly and deliver it to the specified address in time, irrespective of the traffic and the location, they need to travel over the nooks of the streets and make sure they are in time. This challenge the thousands of delivery employees go across the streets on 
their two-wheelers and their employers to face on the ground to make sure that delivery are made on time with profits and positive feedback from the customers.

\subsection{Job Stress and Job Insecurity}

One of the most significant things that affect the productivity of employees is job stress. Stress usually has an effect on the minds of the people and food delivery employees are also experiencing this phenomenon . Organizational and personal factors are the main reason for the stress. It's a physical and psychological effect which results in pressure and multiple demands and not able to cope with the demand of the companies. Both positive and negative strategies are the two different coping mechanisms, but it depends on choice of the people. The positive strategy helps to manage the stress and leads to better performance of the employees, which also helps to increase the satisfaction of the employees [7]

Job insecurity is a condition of unsecured feeling which occur due to nonpermanence of the job. In the present competitive environment, all the jobs makeshift. Job insecurity is the most stressful aspect which leads to unemployment and linked to numerous health outcomes [15]. With regard to mental health it has been associated with emotional symptoms, loss of self-esteem and anxiety.

\section{Research Methodology}

Three major online food delivery companies are considered for this study, they are Swiggy, Zomato and Uber Eats. The employees working for the above companies have been considered as sample. The sample size of the study is 150 respondents working in this food delivery service companies. Convenient Sampling Technique has been adopted for selecting the sample.

\subsection{Statement of the Problem}

The process of ordering food through website or mobile app is the primary aspect in the food delivery industry [14]. The online food delivery services have experienced a robust growth in the recent times. The growth of this sector is increasing up to $15 \%$ every quarter. This due to the increase in the disposable income, urbanization and changing consumer lifestyle. Another main and important reason for this is the increase in the usage of the internet and smart phones. This sector has grown enormously in urban areas and in some rural areas. With the booming growth in this service, the employment in this sector has also increased. Many numbers of people are working in the online food delivery service now as full time workers and also as part time workers. However, the employees face a lot of difficulties working in this sector. Some of the main and common problems faced by them are irrationality of payment compared to the amount of work done, lack of career development, insecurity of the job, harsh behaviour of customers, and traffic congestion. Hence, the study focuses on the level of job stress and insecurity among the employees in food delivery services [7]

\subsection{Objectives}

To study the factors affecting job stress and insecurity of the employees in the food delivery services.

To find out the association between job stress and insecurity.

\subsection{Scope}

The study tends to identify the perception of the employees in the food delivery services towards their job and to give more insight about the various problems faced by them regarding their job stress and insecurity [7]. Further the study will help with the better understanding about the employees in this sector. 


\subsection{Research gap}

The study on Job stress and insecurity in different segment of employees are taken up by various Researchers. Hardly very few studies have done in food delivery system and no studies were taken on aspects covering job stress and insecurity of employees in food delivery services. Hence, this study has to fulfill this research gap, providing with more information.

\section{Findings and Analysis}

\subsection{Demographic profile of the food delivery employees}

- 36 per cent of the respondents are 21 to 30 years old, out of 150 employees, 92.7 per cent are male, 51.3 per cent are unmarried and 58.7 per cent are under graduates. 47.3 per cent of the respondents have completed engineering education.

- 44.7 per cent of the respondents earning Rs. 20,000 to Rs.29, 999 as their monthly income.

- 64.7 per cent of the respondents are employees of swiggy 18 per cent are zomato employees and 17.3 per cent are uber eats employees.

- 70 per cent of the respondents work full time shift and 47.3 per cent of the respondents work for 10 to 12 hours a day.

\subsection{Descriptive statistics}

To find job stress 14 job related factors have been considered to find the stress level of the Employees. Descriptive statistics has applied to find the various factors affecting their job stress

\section{Table -1 Factors Affecting Job Stress (Appendix 1)}

From the Table -1 it is inferred that the factors
"Constant pressure to work fast" and "Difficulty to keep up with time deadlines" has the highest mean value of 2.813 and 2.766 respectively. Hence, the respondent's level of stress is more towards these two factors when compared to other factors measuring their job stress. The factors "Unkind and hurtful responses from customers" and "low confidence and low self-esteem" has the lowest mean value of 1.813 and 1.833 . Hence, the respondent's level of stress is less towards these two factors when compared to other factors measuring their job stress.

Table- 2 Overall Job Stress of the

\section{Respondents}

\section{(Appendix 2)}

From the Table- 2 it's observed that the average mean value for the level of job stress of the respondents is 2.27 which indicate a higher score given by respondents for their level of stress towards the factors measuring their job stress. Hence, the employees are fairly stressed with their job.

\section{ANOVA}

ANOVA has been applied to find whether there is any significant difference in the mean satisfaction scores of job stress among the respondents classified based on various personal factors.

Table-3 ANOVA Job Stress Vs Personal Factors (Appendix 3)

The ANOVA result shows that at $5 \%$ level of significance. The level of job stress have no significant difference among the respondents classified based on educational qualification, stream of education, monthly income and the company they are working. Hence, the hypothesis is accepted.

With respect to Age and working hours significant difference has been found among the respondents. Hence, the hypothesis is rejected. The employees fall under the age category of 31-40 years felt more stress when compared to others. Likewise the employees who are working more than 12 hours are undergoing job 
stress when compared to other employees.

\subsection{Job Insecurity}

Ten factors have been considered to find the level of insecurity among the employees. Descriptive statistics has been applied to find the various factors affecting job insecurity.

\section{Table-4 Descriptive Statistics- Job Security (Appendix 4)}

It is noted that the factors "Prior information about the changes to be made with respect to their job" and "No fear of losing the job in near future" has the highest mean value of 2.800 and 2.773 respectively. Hence, the level of insecurity of respondents towards these two factors is more when compared to other factors measuring their job insecurity. The factors "No difficulty in finding a new job" and "Stable source of income" has the lowest mean value of 2.240 and 2.413. Hence, the level of insecurity of the respondents towards these two factors is less when compared to other factors measuring their job insecurity.

\section{Table-5 Overall Job Insecurity (Appendix -5)}

Table - 5 depicts that the average mean for the level of agreement towards the various factors measuring job insecurity is 2.796 which indicates a higher score given by respondents for their level of agreement towards the factors measuring their job insecurity. Hence, the employees are fairly insecure with their job.

\subsection{ANOVA}

ANOVA has been applied to find the significance difference if any among job insecurity scores and demographic profile of the respondents.

\section{Table-6 Job Insecurity Vs Demographic Profile (Appendix - 6)}

The ANOVA results show that at 5\% level of significance. The level of job stress have no significant influence among the respondents classified based on their age,
Educational qualification, Stream of education, Monthly income, Company they are working and working hours. Hence the hypothesis is accepted. The result reveals that irrespective of various demographic profile the employees felt insecurity in their job.

\subsection{Correlation}

Pearson ${ }^{\text {ee }}$ correlation has been applied to find out whether there is any significant relationship between job stress and insecurity [7] the results are presented in the following paragraphs.

\section{Table-7 Correlation - Job Stress and} Job Insecurity (Appendix - 7)

Correlation result shows that the Pearson's correlation value is 0.279 . Positive correlation has been found between job satisfaction and insecurity. The results are statistically significant as the significance value of 0.01 is less than 0.05 . Hence, when the job insecurity increases, the job stress of the respondents also increases.

\section{Suggestions}

The company must work towards forming a grievance appraisal committee to solve employees' work-related issues and also provide the needed training to the workers with the view to reduce the stress of the workers.

$>$ Considering the huge amount of traffic congestions during peak hours in the city centres, the delivery deadlines given to the employees can be extended.

$>$ A proper communication channel must be formed to pass on the information to the employees regarding the changes to be made in their job.

$>$ The society should give respect to the workers of the food delivery without degrading them. 


\section{Conclusion}

In this research an analysis has been made to study the job stress and job insecurity of employees in food delivery services. Employees are the most main asset of any organization. The success or failure of an organization depends upon the satisfaction of its employees. This is even more significant in newly budding industries like the food delivery services. Because of the lack of recognition, career development and inability to give suggestions the job satisfaction is less in this sector. Just salary and incentives alone cannot provide a wholesome satisfaction to the employees. The two other major factors influencing job satisfaction is the job stress and job insecurity. So by taking tactical measures the security of the employees and a stress free attitude towards their job can be increased, which will lead to an increase in employee's job satisfaction which will ultimately result in the prosperity of the sector.

\section{References}

[1]. Abhijeet Rawal, Sneha Mhatre (2018),"Study on work stress and its impact on employee ${ }^{\text {ee }}$ s productivity with respect to teacher", IOSR Journal of Business and Management, Volume-15, Year -2018, pp.15-23.

[2]. Adithya R., Abhishek Singh, Salma Pathan \& Vaishnav Kanade (2017), "Online Food Ordering System", International Journal of Computer Applications (0975 -8887), Volume 180 -No.6, December 2017

[3]. Afsheen Khalid, Role of Supportive Leadership as a Moderator between Job Stress and Job Performance", Information Management and Business Review Vol. 4, No. 9, Sep 2012, pp. 487-495.

[4].Amir Shani and Abraham Pizam, "Work-Related Depression among Hotel Employees", Cornell Hospitality Quarterly, Vol. 50, No. 4, pp.446-459 (2009)
[5].Goh See-Kwong, Soo-Ryue, Wong Shiun-Yi (2017)," Outsourcing to online food delivery services", Journal of Internet Banking and Commerce, Volume-22, No-2, Year- August 2017, pp: 222-250.

http://www.icommercecentral.com/openaccess/outsourcing-to-online-fooddelivery-services-perspective-of-fbbusiness-owners.pdf

[6].Kavitha,G Sri Gayathri.S (2018) "A study on stress among women police constable", International Journal of pure and applied mathematics, Vol119, Vol 118 vol 8 Sep-2018, pp 38753886

[7]. Meenatchi Somasundari.M (2018), "The association between job stress coping mechanism of job satisfaction and job performance among the selected online food delivery services" International Journal of Science, Engineering and Management (IJSEM) Volume-4, Issue- 7,YearJuly2019,pp:76-106.

https://www.researchgate.net/publication/ 336685454 0 B1074078219

[8].Mayuri Chaturvedi, SumedhaRaavi (2017),"Study on employee job satisfaction in different sectors and to find out the common factors affecting job satisfaction", Volume-7, Issue-1, Year-January 2019, pp:75-98.

[9].Ramya T.J, Bhavani Shree , Lakshmi (2016),"Employee welfare facilities and its impact on employee satisfaction at hotel industry with special reference to Mysore district", International Journal of Engineering Science and Computing,Volume-6, Issue No-12 ,Year- December 2016,pp:122-139.

[10]. Rashmi (2018)," scope of online food industry, to identify the challenge encountered in opting for online food" International Research Journal of Management and Commerce, Volume- 5, Issue-1, YearJanuary 2018, pp:2348-9766 
[11]. Varsha Chavan, Priya Jadhav, Snehal Korade and Priyanka Teli (2015), "Implementing Customizable Online Food Ordering System Using Web Based Application", International Journal of Innovative Science, Engineering \& Technology, Vol 2 Issue 4, April 2015.

[12]. Vijay Bhaskar Reddy, Vijaya. M Venugopal (2018)," Employee job satisfaction in food industry", International Journal of Research in Social Sciences, Volume-8, Issue- 11, Year-November 2018, pp: 565-637.

[13]. Wilfred Isioma Ukpere, Nnenne E Ukandu (2014),'FFactors impacting job satisfaction of employees in the fast food industry in cape town" Mediterranean Journal of Social Sciences, Volume- 5, No -3, YearMarch 2014 pp:54-86.

https://www.mcser.org/journal/index.php/ $\underline{\text { mjss/article/view/2116 }}$
[14]. https://en.wikipedia.org/wiki/Stress

[15]. Dimitra Nella,1 Efharis Panagopoulou et al., "Consequences of Job Insecurity on the Psychological and Physical Health of Greek Civil Servants" Hindawi Publishing Corporation BioMed Research International Volume 2015, Article ID 673623, $\quad$ pp 1-8 https://www.researchgate.net/publication/ 283009976 Consequences of Job Insec urity on the Psychological and Physica 1 Health of Greek Civil Servants

Creative Commons Attribution License 4.0 (Attribution 4.0 International, CC BY 4.0)

This article is published under the terms of the Creative Commons Attribution License 4.0

https://creativecommons.org/licenses/by/4.0/deed.en_US

Table -1 Factors Affecting Job Stress

(Appendix 1)

\begin{tabular}{|l|c|c|c|}
\hline Job Stress - Factors & N & Mean & Std. Deviation \\
\hline Work load is High & 150 & 2.6400 & .52174 \\
\hline Arguments with angry customers & 150 & 1.8933 & .49354 \\
\hline Unkind/hurtful response from customers & 150 & 1.8133 & .62805 \\
\hline Harassments and assaults in workplace & 150 & 2.0800 & .61872 \\
\hline Constant pressure to work fast & 150 & 2.8133 & .42389 \\
\hline Difficulty to keep up with time deadlines & 150 & 2.7667 & .49720 \\
\hline Feeling tired and drained of physical energy & 150 & 2.4200 & .60501 \\
\hline Unkind treatment by hotel workers/owners & 150 & 1.9467 & .63231 \\
\hline Feeling of choosing wrong job/profession & 150 & 2.0467 & .72664 \\
\hline Low confidence level and low self esteem & 150 & 1.8333 & .64938 \\
\hline Skipping meals and loss of appetite & 150 & 1.9333 & .72043 \\
\hline Getting irritated by traffic & 150 & 2.5267 & .66248 \\
\hline Poor sleeping pattern & 150 & 2.0667 & .70155 \\
\hline Working in harsh weather & 150 & 2.5867 & .59287 \\
\hline Being in an accident because of rash driving & 150 & 2.0867 & .85087 \\
\hline Difficulty in finding customer's address & 150 & 2.4533 & .66137 \\
\hline
\end{tabular}


Table- 2 Overall Job Stress of the Respondents (Appendix 2)

\begin{tabular}{|c|c|c|c|c|c|}
\hline \multirow{2}{*}{$\begin{array}{c}\text { Average job stress } \\
\text { score }\end{array}$} & $\mathbf{N}$ & $\begin{array}{c}\text { Minimu } \\
\mathbf{m}\end{array}$ & Maximum & Mean & Std. Deviation \\
\cline { 2 - 6 } & 150 & 1.50 & 3.00 & 2.2733 & .40379 \\
\hline
\end{tabular}

Table-3 ANOVA Job Stress Vs Personal Factors

(Appendix 3)

\begin{tabular}{|c|c|c|c|c|c|c|}
\hline $\begin{array}{l}\text { Personal } \\
\text { Factors }\end{array}$ & & $\begin{array}{l}\text { Sum of } \\
\text { Squares }\end{array}$ & df & $\begin{array}{l}\text { Mean } \\
\text { Square }\end{array}$ & $\mathbf{F}$ & Sig. \\
\hline \multirow{3}{*}{ Age } & $\begin{array}{l}\text { Between } \\
\text { Groups }\end{array}$ & 4.889 & 3 & 1.630 & 12.262 & .000 \\
\hline & Within Groups & 19.404 & 146 & .133 & & \\
\hline & Total & 24.293 & 149 & & & \\
\hline \multirow{3}{*}{ Education } & $\begin{array}{l}\text { Between } \\
\text { Groups }\end{array}$ & .356 & 3 & .119 & .725 & .539 \\
\hline & Within Groups & 23.937 & 146 & .164 & & \\
\hline & Total & 24.293 & 149 & & & \\
\hline \multirow{3}{*}{$\begin{array}{l}\text { Stream of } \\
\text { Education }\end{array}$} & $\begin{array}{l}\text { Between } \\
\text { Groups }\end{array}$ & .538 & 3 & .179 & 1.102 & .350 \\
\hline & Within Groups & 23.756 & 146 & .163 & & \\
\hline & Total & 24.293 & 149 & & & \\
\hline \multirow{3}{*}{$\begin{array}{l}\text { Monthly } \\
\text { Income }\end{array}$} & $\begin{array}{l}\text { Between } \\
\text { Groups }\end{array}$ & 1.167 & 3 & .389 & 2.457 & .065 \\
\hline & Within Groups & 23.126 & 146 & .158 & & \\
\hline & Total & 24.293 & 149 & & & \\
\hline \multirow{3}{*}{$\begin{array}{l}\text { Company } \\
\text { Working }\end{array}$} & $\begin{array}{l}\text { Between } \\
\text { Groups }\end{array}$ & .204 & 2 & .102 & .623 & .538 \\
\hline & Within Groups & 24.089 & 147 & .164 & & \\
\hline & Total & 24.293 & 149 & & & \\
\hline \multirow{3}{*}{$\begin{array}{l}\text { Working } \\
\text { Hours }\end{array}$} & $\begin{array}{l}\text { Between } \\
\text { Groups }\end{array}$ & 1.707 & 3 & .569 & 3.679 & .014 \\
\hline & Within Groups & 22.586 & 146 & .155 & & \\
\hline & Total & 24.293 & 149 & & & \\
\hline
\end{tabular}


Table-4 Descriptive Statistics- Job Security (Appendix 4)

\begin{tabular}{|l|c|c|}
\hline Job Insecurity Factors & Mean & Std. Deviation \\
\hline No threat of losing the job & 2.4533 & .59738 \\
\hline Power to control events affecting the job & 2.4867 & .54015 \\
\hline Proper employment agreement/contract & 2.5200 & .64214 \\
\hline No difficulty in finding a new job & 2.2400 & .83288 \\
\hline Safe and secured future of job & 2.4533 & .58604 \\
\hline Company values my presence/ contribution & 2.4667 & .64159 \\
\hline Stable source of income & 2.4133 & .74353 \\
\hline $\begin{array}{l}\text { No threat of changes in the incentive } \\
\text { scheme }\end{array}$ & 2.7467 & .53328 \\
\hline No fear of losing the job in near future & 2.7733 & .46555 \\
\hline Prior information about changes to be made & 2.8000 & .43350 \\
\hline
\end{tabular}

Table-5 Overall Job Insecurity (Appendix -5)

\begin{tabular}{|c|c|c|c|c|c|}
\hline $\begin{array}{c}\text { Average job insecurity } \\
\text { score }\end{array}$ & $\mathbf{N}$ & Minimum & Maximum & Mean & Std. Deviation \\
\cline { 2 - 6 } & 150 & 2.00 & 3.00 & 2.7967 & .34804 \\
\hline
\end{tabular}


Table-6 Job Insecurity Vs Demographic Profile

(Appendix - 6)

\begin{tabular}{|c|c|c|c|c|c|c|}
\hline $\begin{array}{l}\text { Personal } \\
\text { Factors }\end{array}$ & & $\begin{array}{l}\text { Sum of } \\
\text { Squares }\end{array}$ & df & $\begin{array}{l}\text { Mean } \\
\text { Square }\end{array}$ & $\mathbf{F}$ & Sig. \\
\hline \multirow{3}{*}{ Age } & Between Groups & .536 & 3 & .179 & 1.488 & .220 \\
\hline & Within Groups & 17.513 & 146 & .120 & & \\
\hline & Total & 18.048 & 149 & & & \\
\hline \multirow{3}{*}{ Education } & Between Groups & .155 & 3 & .052 & .421 & .738 \\
\hline & Within Groups & 17.893 & 146 & .123 & & \\
\hline & Total & 18.048 & 149 & & & \\
\hline \multirow{3}{*}{$\begin{array}{l}\text { Stream of } \\
\text { Education }\end{array}$} & Between Groups & .331 & 3 & .110 & .910 & .438 \\
\hline & Within Groups & 17.717 & 146 & .121 & & \\
\hline & Total & 18.048 & 149 & & & \\
\hline \multirow{3}{*}{$\begin{array}{l}\text { Monthly } \\
\text { Income }\end{array}$} & Between Groups & .107 & 3 & .036 & .291 & .832 \\
\hline & Within Groups & 17.941 & 146 & .123 & & \\
\hline & Total & 18.048 & 149 & & & \\
\hline \multirow{3}{*}{$\begin{array}{l}\text { Company } \\
\text { Working }\end{array}$} & Between Groups & .183 & 2 & .092 & .755 & .472 \\
\hline & Within Groups & 17.865 & 147 & .122 & & \\
\hline & Total & 18.048 & 149 & & & \\
\hline \multirow{3}{*}{$\begin{array}{l}\text { Working } \\
\text { Hours }\end{array}$} & Between Groups & .349 & 3 & .116 & .959 & .414 \\
\hline & Within Groups & 17.699 & 146 & .121 & & \\
\hline & Total & 18.048 & 149 & & & \\
\hline
\end{tabular}

Table-7 Correlation - Job Stress and Job Insecurity (Appendix - 7)

\begin{tabular}{|c|c|c|c|}
\hline \\
\hline & & $\begin{array}{r}\text { Job } \\
\text { insecurity }\end{array}$ & Job stress \\
\hline \multirow[t]{2}{*}{ Job insecurity } & $\begin{array}{l}\text { Pearson } \\
\text { Correlation }\end{array}$ & 1 & $.279^{* *}$ \\
\hline & Sig. (2-tailed) & & .001 \\
\hline \multirow[t]{2}{*}{ Job stress } & $\begin{array}{l}\text { Pearson } \\
\text { Correlation }\end{array}$ & $.279^{* *}$ & 1 \\
\hline & Sig. (2-tailed) & .001 & \\
\hline
\end{tabular}

